\title{
Explaining the Absence of a Genuine European Social-Democrat Consensus: the Case of 'Une Stratégie pour la Solidarité'
}

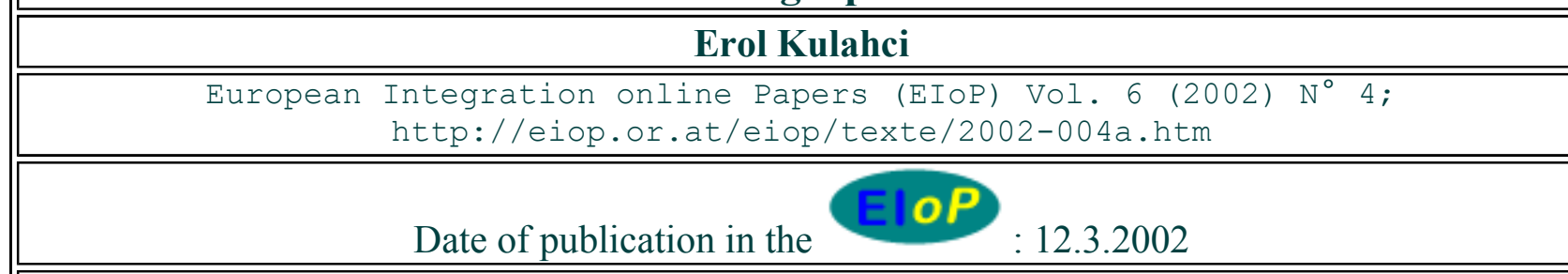

| Full text $\mid$ Back to homepage | PDF |

| This paper's comments page | Send your comment! to this paper |

\section{Keywords}

fiscal policy, governance, harmonisation, integration theory, legitimacy, networks, policy analysis, political parties, regulations, supranationalism, political science

\begin{tabular}{|l|}
\hline \hline \multicolumn{1}{|c|}{ Abstract } \\
\hline Some academic circles have pointed out that the European Union and its Member States suffer \\
from a legitimacy deficit closely linked to the current fiscal policies. In a context which was \\
characterised by the major presence of Labour, Socialist and Social Democrat Parties in the \\
Member States' governments, this article draws attention to Une Stratégie pour la Solidarite of the \\
Party of European Socialists (PES). It argues that this strategy is just a nominal one. Three \\
theoretical assumptions are explored to explain this: the relation between the fiscal policies in the \\
EU and the PES; the emergence of three types of conflicts between the member parties; and the \\
absence of an effective 'pusher' strategy.
\end{tabular}

Kurzfassung

Eine Reihe akademischer Gruppen hat ausgeführt, dass die Europäische Union und ihre

Mitgliedstaaten an einem Legitimitätsdefizit leiden, welches eng mit den derzeitigen

Fiskalpolitiken zusammenhängt. In einer Situation, die durch die wesentliche Beteiligung von

Arbeiter-, sozialistischen und sozialdemokratischen Parteien in den Regierungen der

Mitgliedstaaten gekennzeichnet ist, lenkt dieser Artikel die Aufmerksamkeit auf "Eine Strategie für die Solidarität der Partei der Europäischen Sozialisten (SPE)". Es wird festgestellt, dass diese Strategie lediglich dem Namen nach existiert. Drei theoretische Voraussetzungen werden untersucht, um dies zu erklären: das Verhältnis zwischen den Fiskalpolitiken in der EU und der SPE; das Auftauchen von drei Konflikttypen zwischen den Mitgliedsparteien; und das Fehlen einer effektiven Push-Strategie.

\section{The author}

Erol Kulahci, is researcher at the Centre d'étude de la vie politique of the Institut d'études européennes, Université Libre de Bruxelles ; email: Erol.Kulahci@ulb.ac.be. 


\begin{tabular}{|c||}
\hline $\begin{array}{c}\text { Explaining the Absence of a Genuine European Social-Democrat Consensus: The } \\
\left.\text { Case of 'Une Stratégie pour la Solidarité' }{ }^{*}\right)\end{array}$ \\
\hline \hline Erol Kulahci \\
\hline \hline European Integration online Papers (EIoP) Vol. $6(2002) \quad N^{\circ} 4 ;$ \\
http://eiop.or.at/eiop/texte/2002-004a.htm \\
Date of Publication in EloP $: 12.3 .2002$ \\
\hline \hline | Abstract | Back to homepage | PDF | \\
\hline This paper's comments page | Send your comment! to this paper |
\end{tabular}

\section{Contents:}

- 1. Introduction

- 2. The Conceptual Framework

- 3. Between Competition and Cooperation: The Evolution of Fiscal Policies within the EU

- 4. Why the PES did not Succeed in Constructing a Genuine 'Strategie pour la Solidarité' ?

- 4.1 The policy narratives

- 4.2 The Busquin questionnaire

- 4.3 The implict conflicts revealed by the answers to the questionnaire

- 4.4 Intimate cooperation between the secretariat and the president

- 4.5 The reactions of the member parties to the successive drafts

○ 4.6 The strategy for solidarity, the EG and the joint German-British approach

- 5. Conclusions

- References

\section{Introduction ${ }^{\uparrow}$}

This article has the aim to answer the following research question. To what extent does the transnational interaction between the Labour, Socialist and Social-Democrat parties within the Party of European Socialists (PES) constitute an answer to the European Union (EU)'s fiscal policy deficit? The number of social democratic parties in the EcoFin and in the European Council begs the question as to their influence. In that respect, we are going to describe and explain why a genuine consensus did not emerge within the PES. All the more so, since the parties in government of the PES were a majority within EcoFin and the European Council. The time period taken into consideration starts from 1996 until the begining of 1999. In this introduction, the paper will present, first, the organisational evolution of the PES ; second, the main legitimacy issue raised by fiscal policies ; and, third, Simon Hix's assesment of where the PES stands today.

The Party of European Socialists (PES) was created in order to constitute a forum for Labour, Socialist and Social-Democrat parties in the European Union from which new thoughts and new actions could be produced (Delwit 1995: 282-3; see also Lazar 1996: 44). Indeed, the former President of the PES, Willy Claes, decided that parties-in-government and parties-in-opposition should be represented in the Party Leaders' Meeting (PLM). The aim was not only to reach coherence amongst all the leaders but also to project it on to the EU political process. Thus, the PLM that took place prior to the Birmingham European Council summit in 1992 opened the avenue for regular meetings of top Socialist leaders, Prime Ministers, Ministers of Foreign Affairs and Commissioners prior to each European Council. Following the French presidency of the EU (the first 
semester of 1995), the new president of the PES, Rudolf Scharping, decided that at some point during the leaders' meeting, leaders of parties-in-opposition should leave the table for the leaders of parties-in-government to allow the Heads of states to have a genuine and in depth discussion. This is known in PES's jargon as the European Council Participants' Meeting (ECPM). Under the presidency of Scharping, the first meeting of PES Ecofin Group (EG) took place on $6^{\text {th }}$ March, 1996. Since then, the EG has met at least twice a year and links together Ecofin Ministers, Socialist Commissioners and representatives of PES member parties-in-opposition (Beumer and Tuytens 1999: 3). Moreover, a Working Group on Fiscal policy (WGF) was set up allowing the representatives of the leaders to debate. Regarding the connection between the PES' elites at the PLM, ECPM, EG and WGF levels, the role of the PES' Secretariat has been crucial. These institutions constitute the basis of the transnational interaction between the Labour, Socialist and Social-Democrat Parties under the PES' auspices.

At the end of the 1980s, the issue of fiscal policy has emerged within the OECD countries (Messere, 1993a and 1993b). In the 1990's, fiscal policies have raised problems of legitimacy both at Member State and at EU levels. The first problem is the link between fiscal policy and the representation deficits. Williams illustrated this argument by the famous sentence of Lord Camden symbolising the American Revolution : "Taxation and representation are inseparable ... whatever is a man's own, is absolutely his own; no man has a right to take it from him without his consent ... whoever does it, commits a robbery; he throws down and destroys the distinction between liberty and slavery. (Lord Camden, House of Lords debate, 7 March 1766)" (Williams, 1998 : 1).

The second issue is about fiscal competition. Different political visions do exist. For Edwards and Keen, two " widely divergent views dominate both the academic literature and the policy debate. In one, tax competition is an essentially straightforward instance of the presumption that noncooperative behaviour will lead to inefficient outcome (...) The second view is radically different. It sees tax competition as serving a valuable purpose in supplementing inadequate constitutional constraints on the intrinsic pressures towards excessively high tax rates implied by policy-makers' pursuit of their own interests » (Edwards and Keen, 1994 : 1-2). For Eijffinger and De Haan, there are also two competing visions « Those who regard the state as a facility to maximize its citizens'welfare are more inclined to reject tax competition, as it will cause important allocative distortions. Those who consider the state as a leviathan that pursues the interests of politicians and bureaucrats see tax competition as a means to stop public sector growth $»$. These two visions predict the same effect : governments will reduce their spendings (Eijffinger and De Haan, 2001 : 101). In that respect, Fritz Scharpf points out that fiscal competition has a clear impact on revenue collecting, its eventual distribution and the conservation of activites - like jobs (Scharpf, 1999 : 99-100). All in all, some political circles do consider that fiscal competition is legitimate while others take the opposite view.

Simon Hix analysed the problematics of the PES and the legitimacy of EU socio-economic policy. He distinguishes the left position from the right position along the dirigiste/laissez-faire dimension of politics (Hix 1995: 539). According to Hix, the fiscal position of the PES is a left position (Hix 1995: 542) characterised by the fiscal harmonisation and minimum tax rates (Hix 1995: 539).

Figure 1

Hix used a similar methodology to that of the European Consortium for Political Research on political manifestos (Hix 1995: 541 and 547). His data are relevant to determine the position of the federation if we bear in mind that Leaders' declarations have a media objective and the PES' manifestoes have an electoral purpose. 
In contrast, the present paper will be more focussed on the attemps within the PES to conceptualise Une Stratégie pour la Solidarité. In that respect, it will proceed by presenting the conceptual framework.

\section{The Conceptual Framework}

Let's present briefly the analytical arguments of the other academic circles. On the one hand, Hix's contribution is very much linked to the research theme as he characterizes the PES' position along the "dirigiste-laissez-faire" and "libertarian-authoritarian" axes (Hix, 1995). The work of reference of Hix and Lord is also very much linked to the theme. They depict the position of the PES along the "left-right" and the "intergovernmental-supranational" axis (Hix and Lord, 1998). The article of Johansson is also to an extent close to the problematics as he analyses the influence of the PES on the employment title of the Amsterdam Treaty (Johansson, 1999). The contribution of Ladrech is much more related with the PES and its influence on the agenda of the European Union (Ladrech, 2000). Last but not least, the contribution of Andreas Aust explores the hypothesis of the transition from Euro-keynesianism to the Third Way by paying particular attention to globalisation and europeanisation as well as to the classcial distinction of strategical orientations according to Hirschman: exit, voice and adaptation of member parties (Aust, 2001).

On the other hand, the tracks that these authors suggest are different: the study of the position of the PES along two axis by using comparative politics; the influence of the PES on the agenda by using the concept of "party networks"; the analysis of the influence of the PES on EU decisions by combining transnational and neo-functionalist approaches, and the descriptive-empirical approach of Aust.

In contrast, this paper refers to an inductive approach originating from previous case-studies. Three theoretical assumptions will be explored to account for the absence of a genuine consensus within the PES.

Firstly, it is important to consider the 'dialetical relationship' between the PES and fiscal policy (Marsh and Smith, 2000). It is necessary to discover to what extent the PES has developed activities on particular issues, and to what extent the EU has developed activities on the same issues.

Afterwards, the cross-checking of the results of these activities is also important in order to observe the input of the PES - if there is any input - and the extent to which the policy development in a particular area has an impact on the consensus-seeking activities of the PES. In conceptual terms, the reference is the contribution of Guy Hermet, Bertrand Badie, Pierre Birnbaum and Philippe Braud. They describe consensus as an informal agreement which does not result from a vote (Hermet et al., 1998: 63). The first group of questions is conceived to observe if there is consensus or disagreement within the PES: is the matter of consensus a proposal originating from the European integration logic or from the PES? What are the objectives, the instruments and the level of approaches? Within which organ of the PES is the issue debated: the leaders, the participants to the European Council, the ministerial groups or the working groups?

Secondly, the paper explores the ideas of Fritz Scharpf. He argues that non-negotiable conflicts may and do have their sources in three types of conflicts: ideological preferences, divergent economic interests and institutional conditions. Firstly, the idelological conflicts may arise from "fundamentally conflicting views regarding the proper role of public policy vis-à-vis market forces and regarding the role of European policy vis-à-vis the nation state" (Scharpf, 1999: 78). Andreas Aust, Simon Hix and Christopher Lord refered to this type of conflict (Hix and Lord, 1997: 50; Aust, 2001 :2). Secondly, the fundamental conflicts of economic self-interest may arise "from differences 
in the levels of economic development" between the Member States (Scharpf, 1999: 78). Thirdly, "differences among administrative practices, policy patterns, and institutions" induce institutional conflict (Scharpf, 1999: 80). All in all, it is important to test the relevance of these conflicts within the PES.

Thirdly, it is necessary to analyse the extent to which the relation between the members impedes on the consensus-seeking activities. What are the attitudes of the member parties? What are the emerging coalitions? What are the relations between the organs of the PES? What are the personal strategies? In that respect, we will refer to the analytical distinction operated by Andersen and Liefferink between forerunner and pusher strategies. The forerunner strategies are "primarily based on the domestic politics of the member states (...) and may range from simply defending existing national arrangements, by actively presenting them as 'examples' to others, to implementing unilateral measures as a way to provoke the EU» (Andersen and Liefferink, 1997: 14). The second strategy « can be referred to as constructive 'pusher' strategies. This may involve, for example, putting issues on the agenda of the Council or lobbying the European Parliament (...) An important aspect of the 'pusher' role is the extent to which member states seek to build alliances with each other, something that the procedure for qualified majority voting seems to encourage 》 (Andersen and Liefferink, 1997: 14). Regarding the actors of the PES, this implies a need to try to find out if the actors within the federation have a constructive approach or a 'pure' domestic approach.

Before I proceed to analyse the PES' praxis in detail, it seems useful to present a brief overview of the historical evolution of the EU fiscal framework in order to observe to what extent the development in the EU and, in particular, in its policy process, has been influenced the PES.

\section{Between Competition and Cooperation: The Evolution of Fiscal Policies within the EU}

Fiscal policies have evolved between competition and cooperation in the EU and between its member states. Since the first steps of European integration until the early 1990's, progress were made on EU frontier taxes, directives to harmonize VAT, involving the contribution of the European Court of Justice, the 1612/68 and 1408/71 regulations, the convention and the Scrivener directives for multinational enterprises (Williams, 1998).

However, problems do appear between Member States and are without any easy solutions. Competition is severe between Member States on policy matters such as the taxation of freely circulating goods (in particular, a common taxation), fiscal barriers connected with the free movement of labour, taxing services and service suppliers, taxing multinational enterprises, taxing cross-border savings and tax competition (Messere, 1993; Radaelli, 2000a and 2000b; Williams, 1998). One of the effect of fiscal competition is the imbalance in terms of taxing the factors of production (Eijffinger and De Haan: 104). All in all, tax policy covers very different matters. The type of politics around these matters varies considerably.

Recently, the European Commisison tried to gain « momentum ». Since the informal meeting of Verona in April 1996, the Commissionner Mario Monti started to reconceptualise direct tax policy. The discourse of « harmful tax competion » and the use of a « policy forum » helped him. Moreover, the Commission used the « package deal » approach. The EcoFin meeting of December 1997 resulted in an agreement (Radaelli, 1999: 668-675). It includes four elements:

- « a voluntary code of conduct in business taxation », 
- " the commitment to ensure the minimum effective taxation of savings within the Community",

- " the decision to take a closer look at state aid policy»,

- " the decision to resume proposals for a corporate tax directive on interests and royalty payments across borders » (Radaelli, 1999: 674).

\section{Why the PES did not Succeed in Constructing a Genuine 'Strategie pour la Solidarité'?}

Claudio Radaelli is right when he points out that the EU tax ship does not sail any better even when a social democratic wind is blowing. (Radaelli 1999: 677). Regarding « Une Stratégie pour le Solidarité », the paper will focus on six key points:

- the policy narratives;

- the Busquin questionnaire;

- the implict conflicts revealed by the answers of national delegations,

- the cooperation between the secretariat and the president,

- the reactions of the member parties to the successive drafts and

- the debate within the PES-EcoFin and the joint approach between Blair and Schröder.

\subsection{The policy narratives}

On December 1998, the PES-EcoFin presented the last version of its report on Re-Balancing Taxation For Growth, Investment and Employment (PES, 1998). In order to achieve this objective, the report suggested these six following guidelines:

- fiscal coordination as a prerequisite for sound financing of investment and social security,

- support for the Monti package of reforms,

- corporate tax co-ordination that promotes investment in the EU,

- taxing capital gains and taxing income from savings, and

- fighting against fiscal fraud and rebalancing taxation for growth and employment, in particular, by paying attention to the role of environmental taxes and the reduction of taxes on labour.

All in all, the document called for coordination and intervention in all these guidelines in order to avoid « harmful tax competition ».

The starting point of that strategy was the WGF which was settled by the Malmö Congress in June 1997. It was composed of the representatives of the PES' Leaders and was chaired by Busquin. According to the policy adviser working for the PES' Secretariat, the objective of the WGF was to exchange ideas and to compare party positions, as well as to prepare a common PES position (Tuytens 1997: 1).

\subsection{The Busquin questionnaire ${ }^{\uparrow}$}

Busquin started his work by preparing and then sending to the national delegations a questionnaire on tax systems, the link with EMU, fiscal pressure, social security, labour and capital, investors, employment, environment, fiscal harmonisation, institutional procedures and tax evasion (Busquin 1997). In particular, the questionnaire had the objective of identifying the positions of the Member States, and the PES' positions of the member parties. 
From an anlytical angle, the questionnaire did not ask questions on the EU's own taxes, the EU frontier taxes, the taxing of goods, the taxing of services and service suppliers. However, it did focus on taxing the EU citizens, multinational enterprises, cross-border savings and investment, tax systems and favourable tax zones, the imbalance in taxing the factors of production, harmonisation, the institutional dimension, the link between fiscal policy and other policy areas such as employment and social security.

These issues do reveal the main points interesting the ones who drafted the questionnaire. The answers to these questions reveal the main implicit conflict between the members who responded to it.

\subsection{The implict conflicts revealed by the answers to the questionnaire ${ }^{\uparrow}$}

In this respect, half of the members presented their positions (Andersen 1997; Giannitsis 1997; Guibert 1997; Nowotny 1997; Poss 1997; Randzio-Plath 1997; Rexed 1997; Santos 1997). The issues, the positions and the motivations of representatives are identified according to the documents presented by the leaders' representatives within the WGF: Lars Andersen (Danish Socialdemokratiet), Tassos Giannitsis (Panhelenik socialist movement - PASOK), Gérard Guibert (French PS), Edward Nowotny (SPÖ), Joachim Poss (SPD), Christa Randzio Plath (representative of the Socialist Political Group in the European Parliament - SPGEP), Knut Rexed [Swedish Social Democrat and Labour Party - SAP), and José Carlos Gomes Santos (Portuguese PS). Now, the paper will analyse the main conflicts.

On the issue of taxing the European citizens, there was an ideological conflict. Two representatives expressed preferences in favour of European solutions. However, they did not share the same ideas. The SPÖ did want to limit the adavantages of the statute of the non-resident to the foreign persons who are not citizens of an EU member state. The MEP-SPD was in favour of introducing a European tax in order to collect money for the EU budget.

Regarding the taxation of multinational enterprises, the representatives had different agendas. The PS-F did want to discuss the issue of the localisation of transnational firms. The SPD and the MEPSPD supported the Ruding Comittee's conclusions. However, one has to bear in mind that they supported a report which was rejected by the European Commisison and the Member States. In other words, it would not have the chance to gain momentum in the EU policy process.

As far as cross-border investments are concerned, the preferences revealed an ideological conflict in terms of sovereignty versus integration. The SAP considered that low rates are not the key criteria to influence the behaviours of investors. There are many other variables. So, the Swedish delegation was not convinced by the idea that only variation of rates do influence the behaviour of investment. Thus, he was not really in favour of common tax rates for investors. The SPÖ considered that European law should avoid that Member States and regions do compete in terms of offering attractive subsidies to investors. The SD-D asked to come to an agreement on a common and minimum tax rate for the most mobile factors of production.

The fourth issue was about tax systems and favourable tax zones. The delegations whose member state suffered from tax competition asked for intervention. The PASOK, the SAP and the SPD asserted that the main issues were corporate income and tax evasion. A closer look reveals that their « intervention » approach was different. The SAP considered that the autonomous regions should be considered as «third states » if they do not accept a minimum common rules. The PASOK suggested to use fiscal coordination to fight tax evasion. 
The next problem concerns the factors of production. In a recent study, Eijffinger and De Haan point out that «Unbridled tax competition between member states has caused average tax rates on mobile factors of production, notably capital, to fall from 45.5 per cent to less than 35 per cent in the last fifteen years. In the same period, the average tax rate on labour has increased from 34.9 per cent to more than 42.2 per cent $\gg$ (Eijffinger et De Haan: 104). The question of the imbalance between the factors of production was also high on the agenda of the WGF. The SAP and the PASOK did not believe on that issue. However, the SPD, the PS-F and the SPÖ considered this as a salient problem. They wanted interventionist policies. The German asked the code of conduct to banish this imbalance, the French was in favour of re-balancing, the Austrian urged for harmonised taxes on capital and the MEP suggested to use new instruments such as eco-taxes and low taxes for firms who use high intensive labour.

The questionnaire raised also the problem of harmonisation. In that respect, one can observe a clear ideological conflict in terms of sovereignty and integration. For the SAP and the PASOK, fiscal policy is a key instrument of governmental policy. Thus, they supported a national policy approach. However, they submitted the view that their might be some concessions in some matters. In that respect, the SAP was in favour of harmonisation in issues such as savings, VAT and excises on alcohools, tobaco and energy. The PASOK prefered to harmonise, for instance, the taxation of interests and firms. Other delegations supported cleraly the principle of harmonisation. It was the case of the PS-F although it was vague. It was also the case for the SPÖ which was more detailed regarding the matters to harmonise, the rates and the treaty disposition to use. As a precondition, the MEP asked to have standard definition of taxes which could pave the way to minimum tax rates.

The institutional dimension was also considered. The main cleavage was one between those in favour of collective action at the EU level and those favouring a national approach. In that respect, there was, at least, four key points:

- the SAP and the PASOK were for unanimity while the SPÖ and the MEP defended QMV,

- the Greek and the Swedish delegation were quite reluctant to use treaty disposition such as exarticles 101 and 103 while the Austrian and the MEP representatives were in favour,

- the Monti code of conduct: the PASOk and the SAP were in favour of the code. But, the PS-F, the SPÖ and the SPD wanted the code to be binding,

- the directive on taxing CO2: the PASOK was in favour of using fiscal policy to contribute to a better environment. However, the Greek delegation rejected the idea of a tax on $\mathrm{CO} 2$ because it had negative implications for inflation and for competitiveness. In turn, the SAP, the SD-D, the PS-F, the SPÖ and the MEP supported the proposal of the European Commission.

Last but not least, the questionnaire considered the fiscal issue and the problematics of its relation with other policy areas. In that respect, two main conflicts emerged in terms of ideological preferences and institutional conditions. Regarding the relation between fiscal policy and employement, the SAP pointed to its institutional condition: it was not convinced that the uniformisation of European taxes would promote employment. Considering the Swedish experience, the SAP pointed out that, in the long term, employment is independent of taxation level. The SPÖ wanted public intervention in favour of reducing the social contribution of the « employers » to promote employment.

Considering the link between fiscal pressure and social security, there was a clear willingness for intervention. The PASOK, the PS-F and the SPÖ were in favour of increasing VAT. There was also a slight ideological preference by the MEP for a general and vague taxation at the EU level. 
All in all, the ideological preferences ( sovereignty versus integration ; liberalist versus interventionist) were the more salient conflict. These preferences were someties driven by the explicit recognition of economic interests at stake. In addition to this, there was also conflicts in terms of institutional condition, in particular, regarding the domestic experience of some delegations.

\subsection{Intimate cooperation between the secretariat and the president ${ }^{4}$}

Following the expression of party positions around these issues, the first meeting was held on $14^{\text {th }}$ November 1997. An intimate cooperation between the secretariat and the president occured but this was not enough to overcome the reaction of member parties to the successive drafts.

The first proposal on a common fiscal policy was drafted (Busquin 1998a). It was prepared for the second meeting of the WGF. The document supported the Monti Report and an interventionist attitude on fiscal issues such as the taxation of multinational firms, capital taxes and taxing crossborder savings. A new draft (Busquin 1998b) followed the second round table: there were no substantial changes.

The issue of absenteeism was pointed out by the president and the secretariat. In particular, it was noticed that the BLP, the PvdA, the MEP and the POSL wera absent during the first meeting.

The secretariat, then, suggested to give other topics to other delegations in order to involve them in the working group. Moreover, they sought to buil an alliance with parties which had the closest ideological, economic and institutional profile to their own such as the SPÖ. The president followed this advice.

Thus, three new themes were added to the third draft (Busquin 1998c). Firstly, the representative of the SPÖ wrote on the need for policy coordination in order to reduce the social security burden of labour. Then, the topic on environmental taxes in the EU was written by the representative of the SD-D. Finally, the representative of the SAP wrote not only on the protection of the tax base by enlarging and improving the cooperation on fiscal issues, but also on the prevention and fight against tax evasion.

\subsection{The reactions of the member parties to the successive drafts ${ }^{\uparrow}$}

Jeannot Krecké, member of the Luxembourg Socialist and Worker Party (POSL) and President of the POSL parliamentary group within the Luxembourg Parliament, criticized the third draft as it did not take into account the position of the POSL (Krecké 1998). He was of the opinion that tax on income interest of non EU resident or the compulsory communication of information on savings would not constitute a solution to fight harmful tax competition. Moreover, a directive on taxing cross-border savings should be proposed with a directive on corporate taxes and corporate tax system in the Member States. In particular, it should tackle the special regime available in Belgium for regional coordination centres for multinational firms and the Irish corporate tax rate of 10 per cent. Clearly, Luxembourg's reaction was due to its economic interests in terms of preserving its advantage on savings in the fiscal European space.

The representative of the PASOK also made some remarks. He was of the opinion that the debate on taxing firms and cross-border savings should integrate the third states parameter. He suggested to use higher VAT in order to finance social security. In addition to this, he pondered on the impact that eco-taxes might have on inflation, the elasticity of demand for the concerned products and on competition. He was not in favour of this last instrument. 
The fourth (Busquin 1998d) and fifth draft (Busquin 1998e) followed in September. Before the fourth and last meeting of the WGF, different members sent their texts in reaction to the September draft (Balls 1998a; Giannitsis 1998; Jönsson 1998; Randzio-Plath 1998; Sparks 1998). The newcomers were the British LP (represented for the first time by Chris Wales, who was in charge of defending the document written by Edward Balls on behalf of Minister Gordon Brown); Stefan Jönsson replaced Knut Rexed (SAP); and Greg Sparks (for the Irish Labour Party (LP)). What were the reactions to the September draft?

The BLP had almost a liberal approach. It was against: a minimum tax rate on savings or on firms; a binding and constraining code of conduct; and an alternative financing of social security. On the other hand, it was in favour of a collective fight against non-EU countries practising fiscal dumping.

Like the BLP, the PASOK was not in favour of intervention. It suggested the adoption of a code of conduct not only on corporate tax but also on savings and capitals. It was against green tax as it has negative implications for the Greek competitivity with third states and for inflation. Like the BLP, the PASOK was not in favour of adopting a VAT on firms. While the BLP wanted to suppress it, the PASOK conceded to guarantee a balance between labour cost and capital cost.

The SAP was opposed to the idea of a VAT on companies, as the consequence of this would be lower incentives for progress and expansion and would also diminish employment. In congnitive terms, the Irish LP asked for the integration of quantified information regarding the percentage of Gross National Product (GNP) in income taxes, social welfare contributions and environmental taxes.

The final version of the document (Busquin 1998f), entitled Stratégie pour la solidarité appeared following the fourth and last meeting of the WGF. Unsurprisingly, the Busquin approach helped by François Fontaine (the Belgian PS) was 'political'. For instance, the proposal of C. Randsio-Plath was considered as an acceptable proposal while the proposal of E. Balls had just one positive element (Fontaine 1998). To an extent, it explains why there were almost no substantial changes between the draft of September and the final draft. To a certain extent, it also explains why the BLP reacted when it realised that the last draft did not take into account most of its amendment (Balls 1998b).

\subsection{The strategy for solidarity, the EG and the joint German-British approach ${ }^{\uparrow}$}

During the Austrian Council presidency, the Austrian Finance Minister Rudolf Edlinger took the initiative to discuss fiscal issues during the SPÖ presidency of the three EG meetings, co-chaired by Rudolf Edlinger and Edward Nowotny. Among others, the "proactive stratgey" was on the discussion table. However, Gordon Brown, both representative of the British Labour Party (LP) and British Minister of Finance, was opposed to it. The SPÖ, co-represented by Rudolf Edlinger and Edward Nowotny, and the SPD, represented by the German Finance Minister Oskar Lafontaine, backed the text. The PSOE and the French PS also helped the Busquin report. As far as the Nordic member parties of the PES were concerned, they had reservations about the text. All in all, the document did not constitute a framework of reference for the PES' participants in the EcoFin Council.

Moreover, there has been an obvious and striking alliance between the German and the British within the PES' top elites. It manifested itself by a joint declaration of Gerhardt Schröder and Tony Blair in December 1998 (Blair and Schröder 1998). On the one hand, the joint British and German approach was in favour of an intervention but in a very vague terms: 
- 'tough action to combat unfair tax competition in line with the work of the Code of Conduct Group' - which was not binding;

- the removal of discriminatory tax rules and practices 'to prevent the distortion of competition within the EU' with exceptions 'if a Member State can demonstrate that this will damage the competitiveness of Europe vis-à-vis the rest of the world';

- 'enhanced co-operation in the fight against tax abuse and evasion'; and

- 'coordinating action across the EU' where 'tax policy is used to support wider health and environmental objectives' - how to determine it ?

On the other hand, they were in favour of a liberal regime at the EU level. Indeed, the joint approach « does not »:

- 'favour a unified European system of corporate taxation';

- 'measures leading to a higher tax burden and jeopardising competitiveness and jobs in the EU'; and

- 'measures to harmonise personal income tax' as it 'is not necessary for the effective functioning of the single market and is inconsistent with the principle of subsidiarity'.

At the very least, this joint approach reveals differences of conception, not only between $\mathrm{O}$. Lafontaine and G. Schröder, but also between the interventionists who drafted the Stratégie pour la Solidarité and the PES' top German and British elites, two representatives of 'big' Member States. This common approach was the prelude to the Blair-Schröder declaration on the « Third Way/Der Neue Mitte » before the 99 European elections - in great contrast to the « collective » Milan Manifesto.

\section{Conclusions}

This article has demonstrated that the absence of a genuine Social-Democrat consensus on fiscal policy can be understood adequatly when three subjects are given attention: the dialectical relation between the evolution of the EU fiscal policy framework and the PES ; the three types of conflicts ideological preferences, economic interests and institutional conditions; and the interaction between the delegations within and in between the different elite layers of the PES.

The relation between EU fiscal policy and the PES. At the EU level, fiscal policy is, to say the least, complex. Progress have been made in terms of cooperation. However, the 1990's are also characterised by unresolved issues. In that respect, some actors pointed out the lack of cooperation as some governments were enganged in tax competition. With this as background, the European Commission used the discourse of « harmful tax competition » in an attempt to gain momentum for the issue of tax harmonisation and to place it high on the EU agenda. In November 1997, it succeeded as the Monti package was approved by the EcoFin Council.

The PES responded with Une stratégie pour la Solidarité. The document was very interventionist. Indeed, it « welcomed » the Commission's initiative against harmful tax competion and even suggested that the code of conduct should be binding. Then, the report defended the ideas of fiscal coordination for financing investement and social security, taxing firms, taxing cross-border savings and investment, using eco-taxes to reduce the costs of social security for labour and fighting against tax evasion. If we « conceptualise the EU policy process into four stages - agenda-setting, policy formulation, policy decision, and policy implementation » (Richardson, 1996: 5), one can say that the PES played a potential role in terms of policy formulation. However, it was not able to influence the EU policy formulation. Instead, it was the EU policy decision which influenced the PES: the Monti 
package was, at the very least, well echoed within the PES. Moreover, three types of conflicts, pointed out by Scharpf, reveals that the «proactive strategy » was nothing more than a nominal consensus.

Three types of conflicts. During the European Social-Democrat debate, one can point out that the main issues discussed concerned the EU's own taxes, taxing freely circulating goods, taxing the EU's citizens, taxing services and service suppliers, taxing multinational enterprises, taxing cross-border savings and investment, the imbalance between the factors of production, the institutional issues, the links between fiscal policy and other policy areas such as environment and employment policies.

The main conflict was an ideological one. In particular, it mainly saw a cleavage between the liberals and the interventionists, but also opposition between the proponents of national sovereignty and the integrationnists. This was clearly illustrated by the interventionist stance of the Busquin report and the joint liberal approach of Tony Blair and Gerhard Schröder. This conflict was salient in the PESEcoFin: Nowotny and Lafonatine supported the report while Brown rejected it. It was finally illustrated by the debate within the WGF. For instance, the SAP and the PASOK were cleraly against QMV. They were backed by the POSL and BLP.

A second important conflict emerged in terms of economic interests. The POSL was clearly against losing income from harmonising regulations on cross-border savings. This emerged in the WGF as the main arena of transnational partisan debate. The PASOK was against the directive on $\mathrm{CO} 2$ because it had the potential to damage its economic interests in terms of competitivity and inflation.

The last type of conflict was about the institutional conditions. It manifested itself, for instance, on the issue of links between fiscal policy and employment. The SAP was against the uniformisation of European taxes to favour employment because from its experience, there is not a positive correlation between employment and fiscal policy in the long term.

The interaction between the indviduals. Next to these three types of conflicts, one should point out that there was no effective 'pusher' strategies. Its seems that the main strategy that the PES' actors used was the 'forerunner strategy'. Busquin used the questionnaire which reveals the current priority of the Belgians on EU fiscal issues. In that respect, it was too ambitious if one bears in mind that Belgium is a pro-European country and if one keeps in mind that the Belgian socialists are also very interventionist.

What was the attitude of the presidency and the secretariat towards these three types of conflicts ? They kept their strategy of 'forerunner' and sought to build an alliance with parties which had the closest ideological, economic and institutional profile to their own.

Thus, the PES' praxis did not reconcile the different points of views. This lead to serious reaction within the WGF, the EG and amongst the leaders. All in all, the supranational interaction of Labour, Socialist, and Social-Democrat Parties under the auspices of the PES did not result in a consensus on fiscal policy. In other words, it did not solve the legitimacy deficit of fiscal policies in the EU.

\section{References $^{\uparrow}$}

Andersen, Lars (1997) A few general comments on EU tax policy. 
Andersen, Mikael Skou and Liefferink, Duncan (1997) «Introduction : the impact of the pioneers on EU environmental policy », in Andersen, Mikael Skou and Liefferink, Duncan (eds.), European environmental policy. The pioneers, Manchester et New York: Manchester University Press, pp.139.

Aust, Andreas (2001) The Party of European Socialists (PES) and European Employment policies: From « Eurokeynesianism » to " Third Way policies », Grenoble: ECPR, 6-11 April.

Balls, Edward (1998a) Comments on Draft PES Report on Tax Matters, London, 13 October.

Balls, Edward (1998b) Report by PES Working party on Tax Matters, London, 19 November.

Beumer, Antony and Tuytens, Bernard (1999) Etat actuel des réunions pré-Conseil des Ministres PSE et porte-parole des partis, Brussels.

Blair, Tony and Schröder, Gerhardt (1998) EU Taxation: A Joint British and German Approach, December.

Busquin, Philippe (1997) Questionnaire sur la politique fiscale de l'UE, October.

Busquin, Philippe (1998a) Draft paper on tax matters, First version, February.

Busquin, Philippe (1998b) Draft paper on tax matters, Second version, March.

Busquin, Philippe (1998c) Draft paper on tax matters, Third version, April.

Busquin, Philippe (1998d) Draft paper on tax matters, Fourth version.

Busquin, Philippe (1998e) Draft paper on tax matters, Fifth version, September.

Busquin, Philippe (1998f) Une stratégie pour la solidarité. Rapport sur la fiscalité, October.

Delwit, Pascal (1995) Les partis socialistes et l'intégration européenne: France, Grande-Bretagne, Belgique, Editions de l'Université de Bruxelles, Bruxelles.

Ecofin Council (2000) 'Rapport du Conseil 'Ecofin' au Conseil européen sur le paquet fiscal', in Press Release Information, Conseil européen. Réunion des 19 et 20 juin 2000 à Feira. Conclusion de la présidence, Brussels, 20 June, Doc/00/14.

Edwards, Jeremy and Keen, Michael (1994) Tax Competition and Leviathan, London: Institute for fiscal studies.

Eijffinger, Sylvester C.W. and De Haan, Jakob (2000) European Monetary and Fiscal Policy, Oxford: Oxford university Press.

Fontaine, François (1998) Note à l'attention Président du Parti Ph. BUSQUIN, Brussels, 15 October.

Giannitsis, Tassos (1997) Comments on PES questionnaire on tax harmonisation, Athens.

Giannitsis, Tassos (1998) Remarks on the Draft Report on Tax matters to be discussed in the meeting of $16^{\text {th }}$ October 1998, 14 October.

Guibert, Géraud (1997) Contribution pour le groupe de travail du Parti Socialiste Européen sur la 
fiscalité.

Hermet, Guy et. al (1998) Dictionnaire de la science politique et des institutions politiques, Paris: Armand Colin.

Hix, Simon (1995) 'Parties at the European Level and the Legitimacy of EU Socio-Economic policy', Journal of Common Market Studies, 33(4): 527-54.

Hix, Simon and Lord, Christopher (1997) Political Parties in the European Union, London, MacMillan.

Johansson, Karl-Magnus (1999) 'Tracing the employment title in the Amsterdam treaty: uncovering transnational coalitions', Journal of European Public Policy, 6(1): 85-101.

Jeannot Krecké (1998) Note à l'attention des membres du groupe de travail fiscalité du PSE, présidé par Philippe Busquin, Luxembourg.

Jönsson, Stefan (1998) Apologies, Stockholm, 15 October.

Ladrech, Robert (2000) Social democracy and the Challenge of European Union, London: Lynne Rienner Publishers.

Lazar, Marc (ed.) (1996) La Gauche en Europe depuis 1945. Invariants et mutations du socialisme européen, Paris: Presses Universitaires de France.

Marsh, David and Smith, Martin (2000) 'Understanding Policy Networks: towards a Dialectical Approach', Political Studies, 48: 4-21.

Messere, K.C. (1993a) "Some economic and social issues", in K.C. Messere, Tax Policy in OECD Countries. Choices and Conflicts, Amsterdam : IBFD Publications BV.

Messere, K.C. (1993b) "Financing social security benefits", in K.C. Messere, op.cit.

Nowotny, Edward (1997) Comments on PES' questionnaire.

PES 1998) Re-Balancing Taxation For Growth, Investment and Employment.

Poss, Joachim (1997) Shortcomings of the EU tax code.

Radaelli, Claudio (1999) 'Harmful Tax Competition in the EU', Journal of Common Market Studies, 37(4): 661-82.

Radaelli, Claudio (2000a) The Limits of Europeanization: the Difficult Making of European Direct tax Policy. Paper delivered to the Summer School on Europeanization, Siena, 15 July.

Radaelli, Claudio (2000b) The Future of Tax Policy in the EU. From 'Harmful' Tax Competition to EU Corporate Tax Reform, Brussels: Centre for European Policy Studies.

Randzio-Plath, Christa (1997), Questionnaire on the European Union's tax policy. Response by Christa Randzio-Plath.

Randzio-Plath, Christa (1998) Amendments to the Busquin Report, Brussels, 15 October. 
Rexed, Knut (1997) Comments on the tax policy of the European Union and it's Member States.

Richardson, Jeremy (1996) 'Policy-making in the EU. Interest, ideas and garbage cans of primeval soup' in Richardson, Jeremy (ed.), European Union: power and policy-making, London: Routledge, pp.3-23.

Santos, José Carlos Gomes (1997) Tax harmonisation in the European Union and the convergence of fiscal structures-The Portuguese case.

Scharpf, Fritz (1999) Governing in Europe: Effective and Democratic ?, Oxford: Oxford University Press.

Sparks, Greg (1998) Message, Dublin, 13 October.

Tuytens, Bernard (1997) Compte-rendu de la $1^{\text {ère }}$ réunion du groupe de travail du PSE sur la fiscalité. 14 novembre 1997. Présidence: Philippe Busquin (Président du PS-Belgique).

Williams, David (1998) EC Tax Law, London and New York: Longman.

\section{Endnotes ${ }^{\top}$}

(*) A previous version of this paper was presented at the workshop on « European Integration and Transnational Policy-Making », Centre for European Studies of Carleton University, Ottawa, $8^{\text {th }}$ May 2001. Many thanks are due to all those who have commented on it and suggested amendments or improvements, and particularly to the workshop participants, the Centre d'étude de la vie politique-Institut d'études européennes-Université libre de Bruxelles (Cevipol-IEE-ULB), Ana M. Dobre, Colum T. Hatchell, Claudio Radaelli, Michael Nentwich and three EIoP anonymous referees. 


\section{Figure 1}

\section{The PES' ideology and the socio-economic dimensions of politics (cf. Hix 1995: 540).}

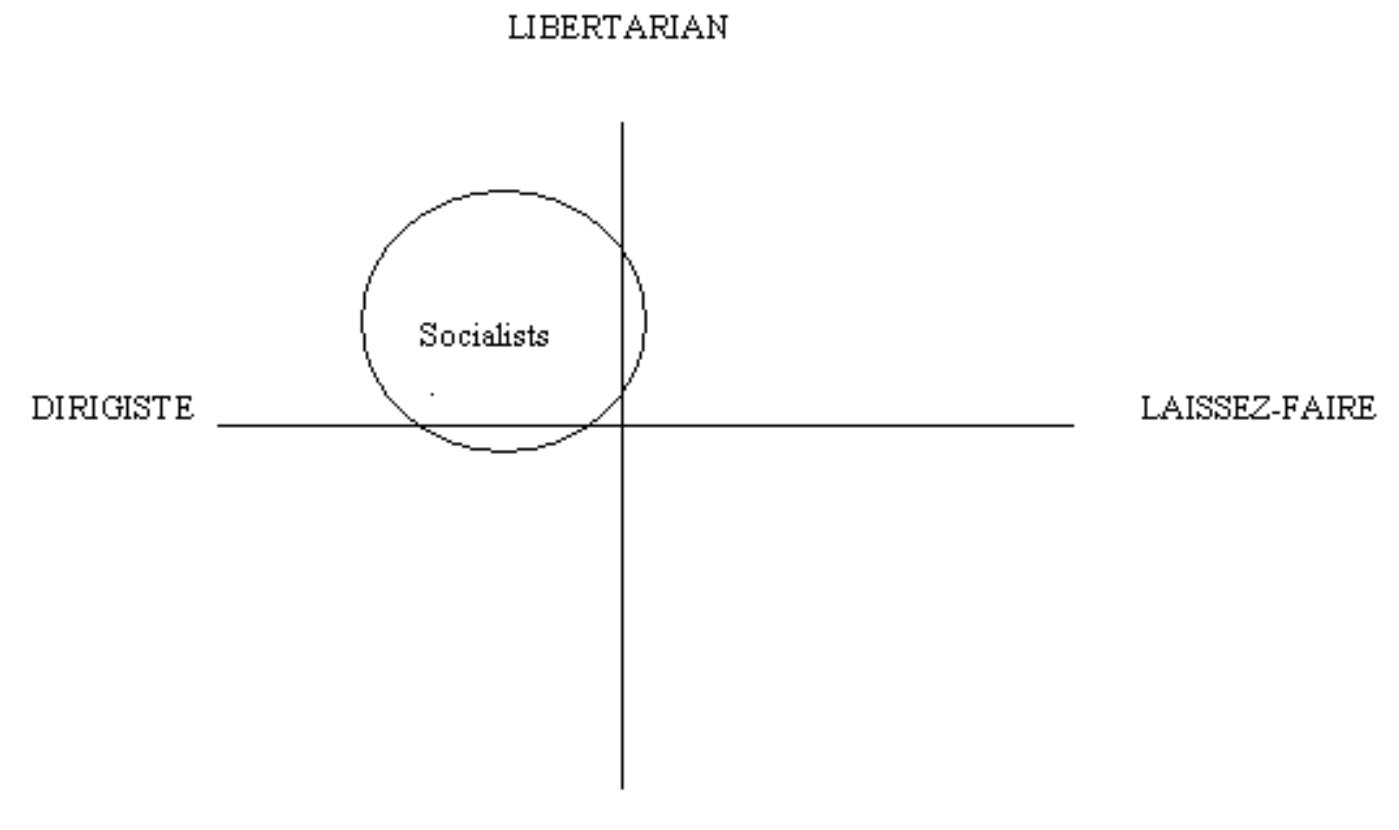

AUTHORITARIAN

formated and tagged by S.H., 11.3.2002 